\title{
Preparation and Characterization of Glucosamine Nanoparticle by Ionic Gelation Method Using Chitosan and Alginate
}

\author{
Yuli Agung Prasetyo, Marline Abdassah, Taofik Rusdiana* \\ Department of Pharmaceutics and Pharmaceutical Technology, Faculty of Pharmacy, Universitas \\ Padjadjaran, Bandung, Indonesia, 45363
}

Received : 24 Sept 2018/Revised : 6 Nov 2018/Accepted : 9 Des 2018/Published 21 Jan 2019

\begin{abstract}
Osteoarthritis is a chronic degenerative disease of the joints that usually treated by NSAID drugs in the long term leading to cardiovascular and gastrointestinal disorders. Glucosamine is a precursor in the formation of progression of joint which have not a significantly side effect. The problem in glucosamine administration occured when it is administered through the oral route resulting in first pass metabolism, while when it is administered via intavena route resulting in insulin resistance. Those problems can be solved by developing glucosamine into nanoglucosamine in order to increase the enzymatic stability which will protect the active ingredient from diminishing by the first pass effect hence the dose can be reduced, consequenlty it will reduce the insulin resistance, and increase the permeation. In this study, the nanoparticles of glucosamine with chitosan polymer and crosslinker alginate was prepared by the ionic gelation method with the principle of continued cross forming polyelectrolyte complexes. This study started from preformulation such as solubility and identify study by FTIR, then the formulations of chitosan: glucosamine: alginate $=5: 1: 1$ (volume ratio) with the variation of concentration in the FI (chitosan: glucosamine: alginate $=0.08 \%: 0.1 \%: 0.08 \%$ ) and FII (chitosan: glucosamine: alginate $=$ $0.1 \%: 0.1 \%: 0.08 \%$ ). Results of nanoparticle characterization by particle size analyzer in the FI showed the better formula indicating a foggy coloid, no precipitation, the $\mathrm{pH}$ was $2.90 \pm 0.05$, and the percent transmittance was $99.35 \%$. The distribution of particle size, polydispersit y index, and zeta potential for the formula I were $76.0 \pm 21.8 \mathrm{~nm} ; 0.300$; and $-0.30 \mathrm{mV}$, respectively. It could be concluded that the nanoparticle system of glucosamine can be better prepared from the $0.08 \%$ of chitosan, $0.1 \%$ of glucosamine and $0.08 \%$ of alginate.
\end{abstract}

Keywords: alginate, chitosan, ionic gelation method, glucosamine nanoparticle

\section{Introduction}

\section{Glucosamine}

(2-amino-2-deoxi- $\beta$-dglucopyranose) is a substance found in the matrix of cartilage and joint fluid of the human joint. Glucosamine is present in almost all soft tissues in the human body with the highest concentration in cartilage (1). Based on case reports, the efficacy of glucosamine is very high, able to control the progression of changes in the anatomical structure of the joints in osteoarthritis (2). The use of oral glucosamine causes the bioavailability of glucosamine to be low by $44 \%$ although its concentration in blood is found to be very high. This is because the first pass metabolism of glucosamine in the liver. In the form of intravenous infusion, glucosamine is found in high doses in the

\footnotetext{
*Corresponding author,

e-mail : t.rusdiana@unpad.ac.id (T. Rusdiana)
}

body and may increase the risk of insulin resistance due to its metabolism in the glycolysis cycle (3). The presence of topical preparations to be a solution in overcoming these problems. However, topical glucosamine preparations circulating in the market have not had the desired efficacy. Therefore, it is recommended to reduce the size of glucosamine to nanoglucosamine. Nanoparticles can increase glucosamine permeation, so the efficacy of glucosamine increases $(4,5)$.

Nanoparticles can be made by ionic gelation method. The ionic gelation is a method of making by crosslinking which strengthens the mechanical strength of particles formed between polymers and crosslinkers (6). Chitosan is a polymer that has been developed because it is biocompatible, biodegradable, non-toxic (7), and is a potential

https://doi.org/10.24198/idjp.v1i1.13924 (C)2019 Prasetyo et al 
biomaterial as a carrier in drug delivery systems (8). Crosslinker polyanion alginate improves the basic structure of chitosan to form a polyelectrolyte complex (9) and prevents the destruction of the active compounds in chitosan nanoparticles (10). From this background, we conducted a study on the preparation of glucosamine nanoparticles with chitosan polymers and alginate crosslinkers using ionic gelation methods including the formulation stages and characterization of glucosamine nanoparticles.

\section{Method}

\subsection{Preformulation}

\subsubsection{Fourier Transform Infrared}

Glucosamine, chitosan, and alginate analyzes were each performed using infrared spectroscopy. For infrared spectroscopy, $1 \mathrm{mg}$ of sample was mixed with $\pm 200 \mathrm{mg} \mathrm{KBr}$, and then made pellet (disc). Measurements using infrared spectroscopy at range of $4600-400 \mathrm{~cm}^{-1}$ (11).

\subsubsection{Solubility}

Glucosamine has a $1: 10$ solubility in water with a pH between 3 to 5 (12). Chitosan with free amino form is not always soluble in water and practically insoluble in $95 \%$ ethanol, other organic solvents and neutral or base solutions at $\mathrm{pH}$ greater than 6.5 , thus requiring acid to dissolve them. Chitosan is soluble in concentrated organic acids as well as dilute, one of which is dilute acetic acid (13). Sodium alginate is water-soluble, insoluble in alcohol, and a hydroalkoloid solution with an alcohol content of more than $30 \%$, and is insoluble in chloroform, ether, and acid with a $\mathrm{pH}$ of less than 3 (14).

\subsection{Formulation}

\subsubsection{Preparation of acetic acid solvent $1.5 \% \mathrm{v} / \mathrm{v}$}

$1.5 \% \mathrm{v} / \mathrm{v}$ acetic acid solvent was prepared by dissolving $15.3 \mathrm{~mL}$ of glacial acetic acid $98 \%$ with distilled distillate to $1000 \mathrm{~mL}$.

\subsubsection{Preparation of glucosamine, chitosan and alginate}

Glucosamine, chitosan and alginate solutions were prepared according to the predetermined concentration of chitosan in $1.5 \% \mathrm{v} / \mathrm{v}$ acetic acid $(0.08 \%, 0.09 \%, 0.10 \%$, and $0.20 \% \mathrm{w} / \mathrm{v})$, Glucosamine in aqua distillata $(0.10 \% \mathrm{w} / \mathrm{v})$, and alginate in aquadistillata $(0.08 \%, 0.09 \%$, and $0.10 \%$ ). Furthermore, sonication for 25 minutes.

\subsubsection{Optimization of glucosamine nanoparticles formula}

Optimization was performed by determining the ratio of the volume of the concentration ratio of the materials used in the formulation of chitosan $(0.08 \%, 0.09 \%, 0.10 \%$, and $0.20 \%$ w / v), glucosamine $(0.10 \% \mathrm{w} / \mathrm{v})$, and alginate $(0.08 \%$, $0.09 \%$, and $0.10 \%)$. Comparison of volumes used are chitosan: glucosamine: alginate $(5: 1: 1$ and 10 : 1 : 1). Glucosamine solution is dropped into chitosan solution by using syringe and homogenized with magnetic stirrer at $1500 \mathrm{rpm}$ for $60 \mathrm{~min}$ at room temperature. Alginate solution is slowly dropped by using a syringe homogenized with a magnetic stirrer at a rate of $1500 \mathrm{rpm}$ for 30 minutes at room temperature. The resulting nanoparticle dispersion system then measured percent (\%) transmittant using UV-Vis spectrophotometry as initial characterization.

\subsubsection{Formulation of glucosamine nanoparticle}

The best optimization results are then formulated. Glucosamine solution is dropped into chitosan solution by using syringe and homogenized with magnetic stirrer at $1500 \mathrm{rpm}$ for $60 \mathrm{~min}$ at room temperature. Alginate solution is slowly dropped by using a syringe homogenized with a magnetic stirrer at a rate of $1500 \mathrm{rpm}$ for 30 minutes at room temperature. The resulting nanoparticle dispersion system then measured percent (\%) transmittant using UV-Vis spectrophotometry as initial characterization. 


\subsection{Characterization}

\subsubsection{Organoleptic}

Physical observations made on the formulation of glucosamine nanoparticles with chitosan polymers and alginate crosslinkers include three things: color, clarity (\% transmittance), and $\mathrm{pH}$. Measurement of transmittance percent by measuring $3 \mathrm{~mL}$ sample using UV-Vis spectrophotometer with wavelength $650 \mathrm{~nm}(15)$.

a. Size and size distribution of particle

Size and particle size distribution were performed with a $100 \mu \mathrm{L}$ nanoparticle suspension dispersed at $50 \mathrm{~mL}$ aquadest and measured immediately with the Particle Size Analyzer (16).

\subsubsection{Zeta potential}

The zeta potential is used to characterize the surface charge nature of the particles (17). The 100 $\mu \mathrm{L}$ nanoparticle suspension was dispersed at $50 \mathrm{~mL}$ aquadest and measured immediately with the Zetasizer tool (16).

\subsubsection{Polydispersity index}

The $100 \mu \mathrm{L}$ nanoparticle suspension was dispersed at $50 \mathrm{~mL}$ aquadest and measured immediately with the Particle Size Analyzer (16).

\subsubsection{Determination of nanoparticle functional groups with FTIR}

The formed nanoparticles are characterized by their infrared spectra using the FTIR instrument.

\section{Result}

\subsection{Preformulation}

Identification of glucosamine standard and sample and also chitosan standard and sample used in this study performed by using the Fourier Transform Infrared Spectroscopy (FTIR), the results were shown in the fig. 1 and 2. The FTIR spectrum of alginate as a cross-linker for nano material have also been identified and shown in the figure 3 .

\subsection{Solubility}

The solubility of glucosamine, chitosan and alginat were performed conventional shake flask method as could be seen in the table 1 .

Table 1. Solubility of glucosamine, chitosan and alginate

\begin{tabular}{ccc}
\hline Substances & Solvent & Solubility \\
\hline Glucosamine & Aquadest & freely \\
& soluble \\
Chitosan & glacial acetate & Soluble \\
& acid $1,5 \%$ & \\
Alginate & Aquadest & soluble \\
\hline
\end{tabular}

\subsection{Formulation}

Nanomaterial of glucosamine was prepared using the formula with the variation of chitosan and alginat as shown in the table 2.

Table 2. Formula of nanoparticle glucosamine

\begin{tabular}{lccc}
\hline \multicolumn{1}{c}{ Formula } & $\begin{array}{c}\text { F0 } \\
(\mathrm{mL})\end{array}$ & $\begin{array}{c}\text { FI } \\
(\mathrm{mL})\end{array}$ & $\begin{array}{c}\text { FII } \\
(\mathrm{mL})\end{array}$ \\
\hline Chitosan $0.08 \% \mathrm{~b} / \mathrm{v}$ & 1 & 5 & - \\
Chitosan $0.1 \% \mathrm{~b} / \mathrm{v}$ & - & - & 5 \\
Glucosamine $0.1 \% \mathrm{~b} / \mathrm{v}$ & - & 1 & 1 \\
Alginate $0.08 \% \mathrm{~b} / \mathrm{v}$ & 1 & 1 & 1 \\
\hline
\end{tabular}

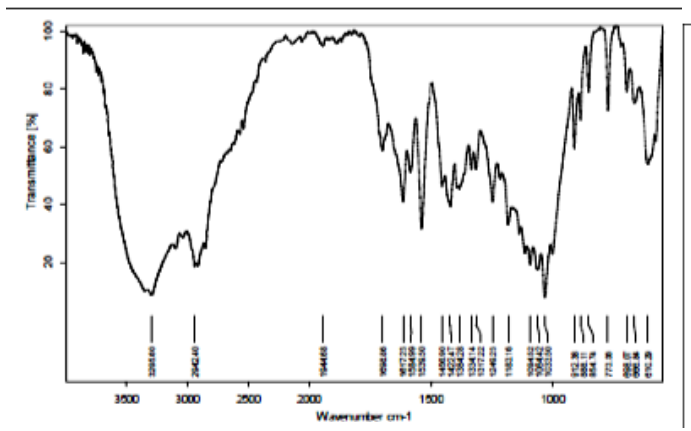

a

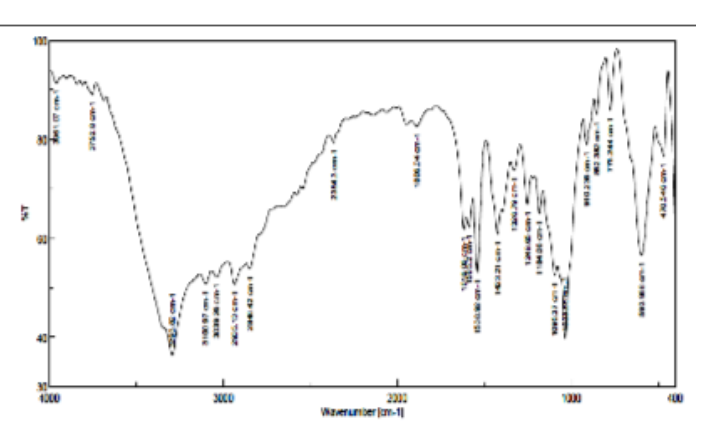

b

Figure 1. FTIR spectrum of glucosamine standard (a) and glucosamine sample (b) 


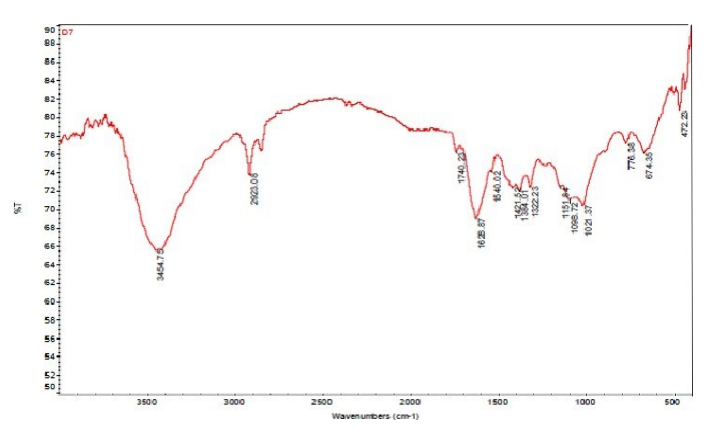

a

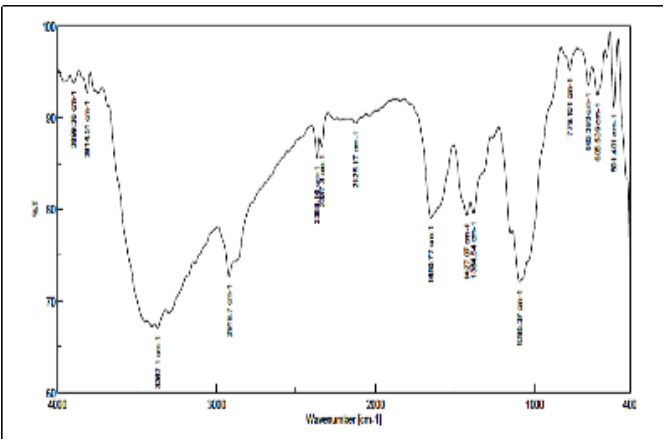

b

Figure 2. FTIR spectrum of chitosan standard (a) and chitosan sample (b)

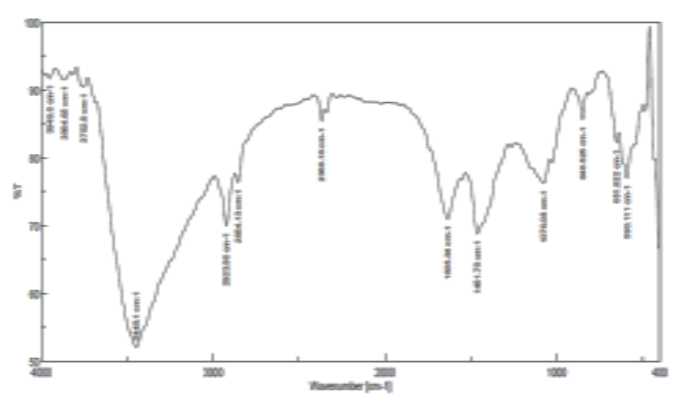

a

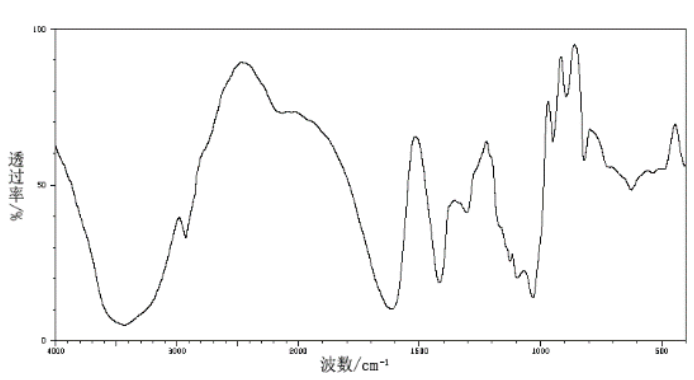

b

Figure 3. FTIR spectrum of alginate reference (a) and alginate sample (b)

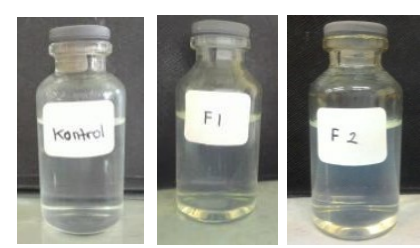

F0

F2

Figure 4. Physical appearance of the nanomaterial formulation : F0, Formula I, and Formula II
The physical appearance of prepared nanomaterial were shown in the figure 4 and explained in the table 3 .

The results of pre-evaluation of glucosamine nanoparticle size performed by the Uv-Vis spectroscopy with measuring the $\%$ transmittance and $\mathrm{pH}$ during 28 days as shown in the table 4 and 5.

Table 3. Physical evaluation of glucosamine nanoparticle

\begin{tabular}{|c|c|c|c|c|c|c|}
\hline \multirow{2}{*}{ Formula } & \multicolumn{6}{|c|}{ Day of } \\
\hline & 0 & 3 & 7 & 14 & 21 & 28 \\
\hline F0 & \multicolumn{4}{|c|}{ Foggy, no precipitate formed } & \multicolumn{2}{|c|}{ precipitate formed } \\
\hline FI & \multicolumn{4}{|c|}{ Foggy, no precipitate formed } & prec & ormed \\
\hline FII & \multicolumn{4}{|c|}{ Foggy, no precipitate formed } & prec & ormed \\
\hline
\end{tabular}

Table 4. Physical evaluation of glucosamine nanoparticles turbidimetry ( $\%$ transmittance)

\begin{tabular}{ccccccc}
\hline \multirow{2}{*}{ Formula } & \multicolumn{7}{c}{ Day- } \\
\cline { 2 - 6 } & 0 & 3 & 7 & 14 & 21 & 28 \\
\hline F0 & $99.59 \%$ & $99.43 \%$ & $99.26 \%$ & $99.13 \%$ & $99.08 \%$ & $99.02 \%$ \\
FI & $99.35 \%$ & $98.87 \%$ & $98.57 \%$ & $98.41 \%$ & $98.35 \%$ & $98.30 \%$ \\
FII & $99.07 \%$ & $98.83 \%$ & $98.41 \%$ & $98.23 \%$ & $98.17 \%$ & $97.87 \%$ \\
\hline
\end{tabular}

Table 5. $\mathrm{pH}$ evaluation of glucosamine nanoparticle

\begin{tabular}{ccccccc}
\hline \multirow{2}{*}{ Formula } & \multicolumn{7}{c}{ Day- } \\
\cline { 2 - 7 } & 0 & 3 & 7 & 14 & 21 & 28 \\
\hline F0 & 3.00 & 3.00 & 3.00 & 3.01 & 3.01 & 3.02 \\
FI & 2.90 & 2.90 & 2.91 & 2.92 & 2.96 & 2.96 \\
FII & 3.05 & 3.05 & 3.06 & 3.05 & 3.08 & 3.08 \\
\hline
\end{tabular}


Table 6. Characteristic Particle Size, Size Distribution, and Average Size Distribution of Glucosamine Nanoparticle

\begin{tabular}{cccccc}
\hline \multirow{2}{*}{ Formula } & \multirow{2}{*}{ Mean particle size $(\mathrm{nm})$} & \multicolumn{3}{c}{ Particle size $(\mathrm{nm})$} & Particle size \\
\cline { 3 - 5 } & & $\mathrm{D}_{10}$ & $\mathrm{D}_{50}$ & $\mathrm{D}_{90}$ & distribution $(\mathrm{nm})$ \\
\hline Control $^{*}$ & 2076.6 & 416.5 & 507.9 & 689.6 & $1076.8 \pm 3992.0$ \\
F0 & 479.8 & 10.7 & 11.3 & 13.1 & $12.3 \pm 9.5$ \\
FI & 396.1 & 56.0 & 66.3 & 96.8 & $76.0 \pm 21.8$ \\
FII & 384.4 & 56.7 & 65.9 & 94.8 & $75.7 \pm 21.0$ \\
\hline
\end{tabular}

*Control = glucosamine standard;

\subsection{Characterization}

\subsubsection{Particle Size Distribution}

The result of particle size, size distribution, and average size distribution of glucosamine nanoparticle by Particle Size Analyzer (PSA) as shown in the table 6 .

\subsubsection{Polidispersity Index}

The result of polydispersity index glucosamine nanoparticle by Particle Size Analyzer (PSA) as shown in the table 7.

\subsubsection{Zeta Potential}

The result of zeta potential glucosamine nanoparticle by Zetasizer and $\mathrm{pH}$ value as shown in the table 8 .

\subsubsection{Determination of Functional Groups of} Nanoparticles with FTIR

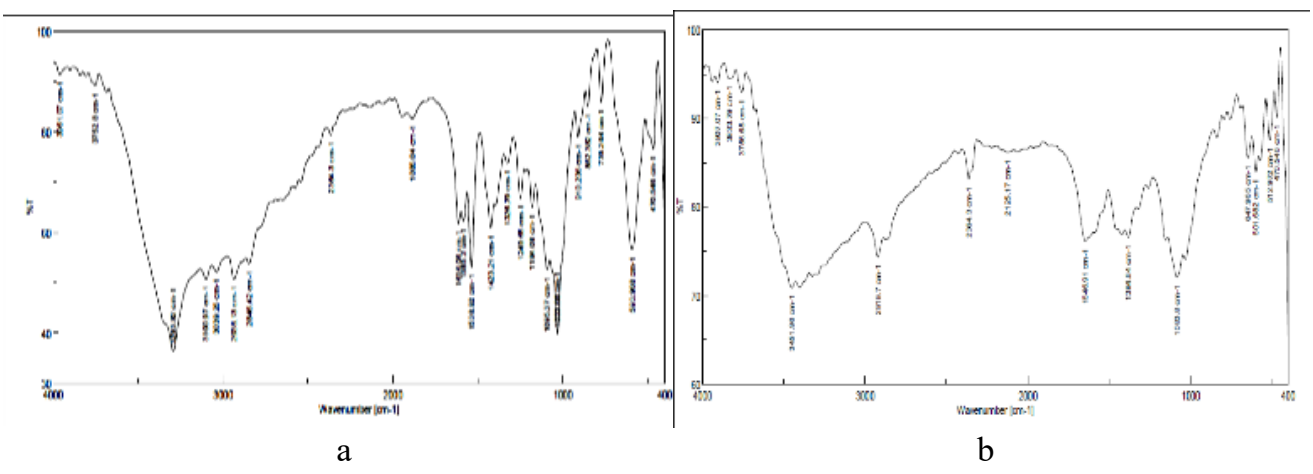

Figure 5. FTIR spectrum of Glucosamine without nanoparticle (a) and Glucosamine Nanoparticle (b)
The result of determination of functional groups of nanoparticles with FTIR shown in the figure 5.

Table 7. Characteristic Polidispersity Index of Glucosamine Nanoparticle

\begin{tabular}{cc}
\hline Formula & Polidipersity Index \\
\hline Control & 0.770 \\
F0 & 0.205 \\
FI & 0.300 \\
FII & 0.350 \\
\hline
\end{tabular}

Table 8. Characteristic zeta potential and $\mathrm{pH}$ value of glucosamine nanoparticle

\begin{tabular}{ccc}
\hline Formula & $\begin{array}{c}\text { zeta potential } \\
(\mathrm{mV})\end{array}$ & $\mathrm{pH}$ value \\
\hline Control & N/A & N/A \\
F0 & N/A & $3.00 \pm 0.057$ \\
F1 & -0.30 & $2.90 \pm 0.057$ \\
F2 & +0.12 & $3.05 \pm 0.057$ \\
\hline
\end{tabular}


Table 9. Functional group of glucosamine reference (21) (Nasution, 2013) and sample

\begin{tabular}{lcc}
\hline \multirow{2}{*}{ Functional Group } & \multicolumn{2}{c}{ Wavelength $\left(\mathrm{cm}^{-1}\right)$} \\
\cline { 2 - 3 } & Sample & Reference \\
\hline O-H & 3293.82 & 3295.60 \\
C-H stretch & 2935.13 & 2942.40 \\
N-H & 1538.92 & 1539.50 \\
C-N amides & 1423.21 & 1422.47 \\
C-N & $1249.65 ; 1184.08$ & $1249.23 ; 1183.16$ \\
Cyclic C-O-C & 1095.37 & 1094.52 \\
Glikosidic bond & 1033.66 & 1033.50 \\
\hline
\end{tabular}

Table 10. Functional group chitosan reference and sample

\begin{tabular}{lcc}
\hline \multicolumn{1}{c}{ Functional Group } & \multicolumn{2}{c}{ Wavelength $\left(\mathrm{cm}^{-1}\right)$} \\
\cline { 2 - 3 } & Sample & Reference \\
\hline N-H primary amines & 3367.1 & 3454.75 \\
C-H alkanes & 2919.7 & 2923.08 \\
Vibration N-H amida primer & 1650.77 & 1628.87 \\
C-H asymmetric from CH CH $_{3}$ & 1427.07 & 1421.52 \\
Vibration C-O secondary alcohol & 1095.37 & 1098.72 \\
\hline
\end{tabular}

Table 11. Functional group of alginate reference and sample

\begin{tabular}{ccc}
\hline Functional Group & \multicolumn{2}{c}{ Wavelength $\left(\mathrm{cm}^{-1}\right)$} \\
\cline { 2 - 3 } OH & Sample & Reference \\
CH aliphatic & 3448.1 & 3420 \\
COO & 2923.56 & 2927 \\
COO & 1635.34 & 1620 \\
CO bending & 1461.78 & 1419 \\
\hline
\end{tabular}

\section{Discussion}

Nanoparticles are solid particles dispersed with a size of 10 - $1000 \mathrm{~nm}$ (18). Nanoparticles can be prepared by top down and bottom up techniques (19). In this study the formation of nanoparticles is done through bottom-up techniques because it is formed by designing atoms or molecules by combining the particles or clusters to form a system through nanometer-sized chemical interactions. Briefly, the teqnique of nanoparticle formation carried out by dissolution of chitosan (polymer) using 1.5\% acetic acid, then mixed with alginate (as a crosslinker) dissolved in aquadestilata resulting in complex polyelectrolyte bonds forming particles of nanometer size (20).

\subsection{Preformulation}

\subsubsection{Fourier Transform Infrared}

Based on the functional groups identified from the glucosamine sample (Figure 1), the presence of
OH $3293.82 \mathrm{~cm}^{-1}, \mathrm{CH}$ stretch $2935.13 \mathrm{~cm}-1, \mathrm{NH}$ $1538.92 \mathrm{~cm}^{-1}, \mathrm{CN}$ amide $1423.21 \mathrm{~cm}^{-1}$,

Respectively in 1249.65 and 1184.08 , cyclic COC $1095.37 \mathrm{~cm}^{-1}$, and glycosidic bond $1033.66 \mathrm{~cm}^{-1}$. Therefore it can be concluded that the glucosamine sample used in this study is in accordance with reference material as in table 9.

Based on the functional groups identified from the chitosan sample (Figure 2), the presence of a primary amine group of $3367.1 \mathrm{~cm}^{-1}, \mathrm{CH}$ alkana $2919.7 \mathrm{~cm}^{-1}$, vibration of $\mathrm{NH}$ amide $1650.77 \mathrm{~cm}^{-1}, \mathrm{CH}$ asymmetric $\mathrm{CH}_{3} 1427.07 \mathrm{~cm}^{-1}$, and secondary alcohol vibration $1095,37 \mathrm{~cm}^{-1}$, it can be concluded that the sample used is chitosan according to the reference material as in the table 10

Based on the functional groups identified from the alginate sample (Figure 3), OH $3448.1 \mathrm{~cm}^{-1}$, $\mathrm{CH}$ aliphatic $2923.56 \mathrm{~cm}^{-1}$, COO 1635,34 $\mathrm{cm}^{-1}$, COO 1461,78 $\mathrm{cm}^{-1}$, and $\mathrm{CO}$ bending $1076,08 \mathrm{~cm}^{-}$ ${ }^{1}$. So it can be concluded that the sample used is alginate according to the reference material as in Table 11. 


\subsubsection{Solubility}

The solubility test results of each sample revealed that 1 gram of glucosamine easily dissolve in $10 \mathrm{~mL}$ aquadestilata (12), $10 \mathrm{~mL} \mathrm{1.5 \%}$ glacial acetic acid, and practically insoluble in $96 \%$ ethanol. One gram of chitosan dissolves in 20 $\mathrm{mL} 1.5 \%$ glacial acetic acid, practically insoluble in aquadestilate and 96\% ethanol (13). One gram of alginate dissolves in $20 \mathrm{~mL}$ of aquadestilate, 20 $\mathrm{ml} 1.5 \%$ glacial acetic acid, and practically insoluble in $96 \%$ ethanol (14).

\subsection{Formulation}

The choice of chitosan as a polymer is based on the advantages of chitosan properties including biocompatible, biodegradable, low toxicity, easily synthesized and easily characterized. The choice of alginate as a crosslinker is based on its properties that can improve the basic structure of chitosan to form a polyelectrolyte complex (9) and prevent the destruction of the active compound glucosamine in chitosan nanoparticles (10). So that glucosamine will be stable in the chitosan nanoparticles.

In this study, chitosan used had a deacetylation degree of $92.30 \%$. The degree of deacetylation of chitosan will affect the onset of aggregation. The higher the degree of deacetylation of chitosan, the lower chitosan acetyl group so that the interaction between ion and hydrogen bonds is getting stronger. Thus, at higher chitosan concentrations, the combined power of chitosan will increase, which will cause aggregate to emerge and form precipitate. Based on this, the chitosan concentration used is below $0.3 \%$ to prevent the formation of particles in micro size (8). Furthermore, glucosamine nanoparticles were prepared with chitosan polymer and alginate crosslinker with ionic gelation. The ionic gelation is followed by the complexity of different polyelectrolytes of charge. In this study, chitosan is a cationic polymer, $\mathrm{NH}_{3}{ }^{+}$, able to react with multivalent anions of alginate, $\mathrm{COO}^{-}$. Hydrophobic interactions and hydrogen bonds induced from the amide group $\left(\mathrm{NH}_{3}{ }^{+}\right)$that will contribute to the gelation process. The ionic gelation process is carried out by mixing the crosslinker phase, alginate, into the drug-polymer phase, chitosan-glucosamine dripwise. The velocity of the droplet is made constant with the assumption of a particle-generated particle size distribution. Gupta and Kompella (2006) (22) explain that in nanoparticles, the force of gravity is not stronger than Brown motion of particles thus making the nanoparticles not settle. Sonication aims to break down compounds or particles of energy generated by the collapse of cavitation. The longer the sonication time, the particle size tends to be more homogeneous and shrink eventually leading to a stable nanoparticle size and less agglomeration.

The result of the optimization of the formula shows that the concentration used has an effect on the percentage $(\%)$ of the transmittance produced. The optimization result of this formula is the first step to predict that glucosamine nanoparticles with chitosan polymer and alginate crosslinker will be formed at a certain concentration. Measurement of percent $(\%)$ of this transmittance utilizes lightinduced activity by particle due to TyndallFaraday effect. At $0.2 \%$ chitosan concentrations downward, the manufacture of nanometer-sized particles $(\mathrm{nm})$ is relatively easier to do, with the effect of alginate concentration on microscale formation less significant. Expected results are percent (\%) transmitters that are above $99 \%$ and the formation of a clear solution becomes transparent.

From the results of physical observations then carried out physical evaluation of nanoparticles to storage for 28 days. Physical evaluation of nanoparticles is done as one part to know the stability of nanoparticles produced. From the nanoparticle formula evaluation physically, it is known that the nanoparticle formula undergoes a change in stability as seen from the value of transmittance percent (\%) which decreases after day 3 , the $\mathrm{pH}$ of the formulation changes on day 7 , and the beginning of sediment formation on the $21^{\text {st }}$ day. That the F0, FI, and FII are unstable during storage. 


\subsection{Characterization}

\subsubsection{Size and size distribution of particle}

The particle size produced was influenced by the concentration of chitosan polymer and alginate crosslinker and the active glucosamine agent used, the minute (minute) of the preparation sonication of each chitosan and alginate concentration, velocity (rpm) and time ( $\mathrm{min}$ ), and magnetic stirrer agitation it shown in table 6 .

\subsubsection{Polidispersity Index}

From the data obtained on glucosamine nanoparticles with chitosan polymer from the controls, F0, FI, and FII respectively of 0.770 , $0.205,0.300$, and 0.350 . This is also in accordance with Avadi's research, et al., (2010) (23) that the polydispersity value of the index close to 0 indicates a homogeneous size dispersion and when it exceeds 0.5 , it indicates high heterogenity. The $\mathrm{pH}$ value become acid because its influence by glacial acetic acid. From these data it can be concluded that the resulting nanoparticle complex is still in the range of polarization index values of theoretical chitosan index and homogeneous size. While the control has a heterogeneous size.

\subsubsection{Zeta Potential}

The interaction between particles has an important role in colloidal stability. The zeta potential is a measure of the repulsive force between particles. Most colloidal systems in water are stabilized by electrostatic forces, the greater the repulsive resistance force among particles, the less the particle's ability to combine to form aggregates. Nanoparticles with zeta potential values greater than $-/+30 \mathrm{mV}$ proved stable in the suspension to prevent aggression (24).

From FI and FII have different zeta potential charges. The positive or negative value of zeta potential is influenced by the charge on the surface of the particles of chitosan containing functional groups, $\mathrm{NH}_{2}$, and alginates containing functional groups, $\mathrm{COOH}$, which can be ionized. In this study
$\mathrm{NH}_{2}$ will be ionized with a positive charge and $\mathrm{COOH}$ will be ionized with a negative charge. The resulting nanoparticle system has a $\mathrm{pH}<3$ which means that the ionization of the carboxyl group ($\mathrm{COOH})$ is inhibited, and the ionization of the amide $\left(\mathrm{NH}_{2}\right)$ group is increased in accordance with the $\mathrm{pH}$-partition rule. In general the zeta potential value is a resultant of cation and anion activity in the nanoparticle system.

The activity of zeta potential decrease by anion is reinforced by decreasing $\mathrm{pH}$ in nanoparticle system. The results obtained the more acid $\mathrm{pH}$ medium, the number of base groups $\left(\mathrm{NH}_{2}\right)$ ionized will be more and more. Increased base groups $\left(\mathrm{NH}_{2}\right)$ ionized increase the positive charge of the particle surface, so that negative charge ions will be absorbed. The higher the zeta potential value, the more stable the nanoparticles are formed. This effect is associated with binding of the anionic group by a long amine group of chitosan to maintain a high electrical value thereby preventing aggregation (23).

In addition to its role in determining the physical stability of the nanoparticles, the resulting zeta potential will affect its effectiveness in the glucosamine delivery system. High nanoparticle loads will facilitate fastening of cell membranes and high cellular uptake due to the bond between the polyanionic alginate and the chitosan polycationic that can facilitate the absorption. The chitosan cationic compound will increase the permeation of the skin, with the components of the phosphatidyl choline and carbohydrate skin tissue found in mammalian cells containing negatively charged groups (25). Then it needs to be added into it stabilizers or surfactants to prevent the particle size from growing (20).

\subsubsection{Determination of functional groups on nanoparticles with FTIR}

On the spectrum shows the reaction between chitosan and alginate used. The reaction occurs when through addition and elimination mechanisms, which alter the functionality of amides or carboxylates. When in the formation of nanoparticles reaction occurs between the carboxylic group (COO-) of alginate and amine 
group $(\mathrm{NH} 3+)$ of chitosan, then on the IR spectra there will be absorption in the region of wave number $(\mathrm{cm}-1)$ : $1740-1630(\mathrm{C}=\mathrm{O})$ And 1630-

$1510(\mathrm{NC}=\mathrm{O})$. In the determination of nanoparticle functional groups, there is known peak at wavelength $1646,91(\mathrm{~cm}-1)$. This indicates a reaction between the carboxylic group (COO-) of the alginate and the amine group $(\mathrm{NH} 3+$ ) of the chitosan. Furthermore there are several peaks of glucosamine that disappear after the nanoparticles are made at the wavelengths 3100.97 and 3039.26 (cm-1). This is because glucosamine has been absorbed in the nanoparticle system, so that glucosamine functional group readings are blocked by chitosan polymers and alginate crosslinkers.

\section{Conclusion}

The formulation of glucosamine nanoparticles is influenced by the concentration and volume ratio of chitosan polymer and alginate crosslinkers. Comparison of the better volume ratio of chitosan: glucosamine: alginate $=5: 1: 1$. Comparison of concentrations of 24 formulas corresponding to the parameters of FI and FII. Comparison of concentration used FI = chitosan: glucosamine: alginate $=0.08 \%: 0.1 \%: 0.08 \%$ and FII $=$ chitosan: glucosamine: alginate $=0.1 \%$ : $0.1 \%$ : $0.08 \%$. Further characterization results, based on physical observation and $\mathrm{pH}$, particle size and particle size, index polydispersity, and zeta potential formula I are better than formula 2 with the result of fog, no sediment, $99.35 \%$ transmittance percent, and PH $2.90 \pm 0.5,396.1$ $\mathrm{nm} ; 76.0 \pm 21.8 \mathrm{~nm}$, PI 0.300, and zeta potential $0.30 \mathrm{mV}$. However, the lack of such a formula is that the nanoparticles formed are still unstable.

\section{Acknowledgement}

We would like to thank Directorate General of Higher Education, Ministry of Research and Technology and Higher Education, The Republic of Indonesia for funding this study. We also thanks Mr. Jaja and Mrs. Yani from the Laboratory of Formulation and Pharmaceutical Technlogy,
Universitas Padjadjaran for the technical assistance.

\section{References}

[1] Miller, K.L., and Clegg, D.O. Glucosamine and Chondroitin Sulfate. Rheum Dis Clin N Am. 2011(37):103-18.

[2] Clegg, D.O., Reda, D.J., Harris, C.L., Klein, M.A., O'Dell, J.R., Hooper, M.M. Glucosamine, Chondroitin Sulfate, and The Two in Combination for Painful Knee Osteoarthritis. N Engl J Med. 2006:795-808;

[3] Simon, R.R., V. Marks, A.R. Leeds, and J.W. Anderson. A Comprehensive Review of Oral Glucosamine Use and Effects on Glucose Metabolism in Normal and Diabetic Individuals. Diabetes/Metabolism Research and Reviews. 2011;27(1):14-27.

[4] Thassu, D. Michel, D., Yashwant, P. Nanoparticulate Drug Delivery System. New York: Informa Healthcare. 2007:327-336.

[5] Marimuthu, M., D. Bennet, and S. Kim, Selfassembled nanoparticles of PLGA-conjugated glucosamine as a sustained transdermal drug delivery vehicle. Polymer Journal, 2012;45:202.

[6] Park, K.K., and Yeo, Y. Microencapsulation Technology. Dalam Swabrick, J. Encyclopedia of Pharmaceutical Technology, 3rd ed. Vol. 4. New York: Informa Healthcare USA; 2007:2317.

[7] Chen, X., Liu, C.S., Liu, C.G., Meng, X.H., Lee, C.M., and Park, H.J. Biochemical Engineering Journal, 2006; 27: 269-274.

[8] Mardliyati, E., Muttaqien, S.E., dan Setyawati, D.R. Sintesis Nanopartikel Kitosan-Trypoly Phosphate Dengan Metode Gelasi Ionik: Pengaruh Konsentrasi Dan Rasio Volume Terhadap Karakteristik Partikel. Prosiding Pertemuan Ilmiah Ilmu Pengetahuan dan Teknologi Bahan 2012. Jakarta: Pusat Teknologi Farmasi dan Medika - BPPT; 2012.

[9] Sugita, P., T. Wukirsari, A. Sjahriza, dan D. Wahyono. Kitosan: Sumber Biomaterial Masa Depan. Bogor. IPB Press; 2009.

[10] Fan, W., Yan, W., Xu, Z., and Ni, H. Colloids and Surfaces B: Biointerfaces. 2012; 90:21-27.

[11] Zhang, H., W. Si-hui, Z. Lin-quan, S. Zengquan. Preparation and Characterization of 
Water-Soluble Chitosan Nanoparticles as Protein Delivery System. Journal of Nanomaterial; 2010.

[12] Sweetman, S.C. Martindale 36 The Complete Drug Reference. London: The Pharmaceutical Press; 2009.

[13] Rowe, R.C. (ed). Handbook of Pharmaceutical Excipients. $6^{\text {th }}$ Edition. Pharmaceutical Press. London. 2009:159161.

[14] Comitte of Food Chemical Codex. Food Chemical Codex. Edisi 5. Washington D.C. The National Academic Press; 2004: 37-38.

[15] Winardi, S., Kusdianto, dan Widiyastuti.. Preparasi Film ZnO-Silika Nanokomposit dengan Metode Sol-Gel. Prosiding Seminar Nasional Teknik Kimia "Kejuangan"; 2011.

[16] Yu-Hsin, L., K. Sonaje, K.M. Lin, J.H. Juang, F.L. Mi, H.W. Yang, and H.W. Sung. Multi-ion-crosslinked Nanoparticles with $\mathrm{pH}$ responsive Characteristics for Oral Delivery of Protein Drugs. J. of Contr. Rel. 2008;132:141-149.

[17] Vaughn, J.M. and Williams R.O. Nanoparticles Engineering. Dalam Swarbrick, James. Encyclopedia of Pharmaceutical Technology Third Edition Volume I. New York: Informa Healthcare USA; 2007: 23842398.

[18] Muller, R.H. and C.M. Keck. Challenges and Solution for The Delivery of Biotech Drugs - A Review of Drug Nanocrystal Technology and Lipid Nanoparticles. J. Biotech. 2004; 113:151-170.
[19] Raval, Amit J., and Patel. Madhabahi M. Preparation and Characterization of Nanoparticles for Solubility and Dissolution Rate Enhancement of Meloxicam. Journal of Pharmaceuticals. 2011; 01: 42-49.

[20] Mauludin, R. dan R.H. Muller. Produksi Nanosuspensi Ibuprofen dengan Menggunakan Metode Homogenisasi Tekanan Tinggi (High Pressure Homogenization-HPH). Dalam Medicinus. 2010; 23(3).

[21] Nasution, A.R.. Pembuatan dan Karakterisasi Glukosamin Hidroklorida dari Kitin Cangkang Belantas (Tachypleus gigas). (Skripsi). Medan. Departemen Kimia FMIPA USU; 2013.

[22] Gupta, R. B. and Kompella, U.B. Nanoparticle technology of drug delivery, Taylor \& Francis Grup, New York. 2006: 4-6, 13-16.

[23] Avadi, M.R., Assal M.M.S., Nasser M., Saideh A., Fatemeh A., Rassoul D., and Morteza R. Preparation and Characterization of Insulin Nanoparticles Using Chitosan Arabic Gum with Ionic Gelation Method. Nanomedicine: Nanotechnology, Biology, and Medicine 2010; 6:58-63.

[24] Mohanraj, V.J., and Chen, Y. Nanoparticle A Review. Tropical Journal of Pharmaceutical Research. 2006; 5:561-573.

[25] Honary, S. and Zahir, F. Effect of Zeta Potential on the Properties of Nano-Drug Delivery Systems - Review (Part 1). Tropical Journal of Pharmaceutical Research. 2013;12 (2): $255-264$. 